\title{
Decision Support System to Determine the Right Department in Higher Education Based on the Interests and Talents of Prospective Students by Applying the AHP Method
}

\author{
Nur Kumala dewi \\ Faculty of Information System, STMIK Muhammadiyah Jakarta, Indonesia \\ ${ }^{*}$ Corresponding author: \\ Email: nkd.mandori@gmail.com
}

\begin{abstract}
The background of this research is how to determine the best choice in determining a major in higher education, with various existing majors, students must be able to choose the right department for themselves, with the right majors, the lectures will be maximized and the student will not experience difficulties. in entering lectures. The method used in this study is to use quantitative methods, based on literature reviews, with literature review methods, it will refer to previous research that has produced something for the wider community, with the development of previous research, this research will become the latest research. . There are several studies that use the AHP method, for example in the field of decision support systems in the field of psychology, the recruitment department of new employees, using the AHP method can determine which employee is the best for a position in a company, this method will help HRD in determining acceptable employees in a company. This research will show how an AHP method can provide the best solution in choosing a department in a college, which is carried out on prospective new students at a university.
\end{abstract}

Keywords: Decision Support System, Department, College, Student, AHP.

\section{INTRODUCTION}

Making choices is indeed not an easy thing, especially in choosing a major in college [1], because the major we choose will determine our future, where we want to work and what part, with the selection of the right department then the future of a student can be determined from the beginning of his study, therefore the selection of the right department must go through stages that are not simple, with these stages it will be able to determine the results in determining the chosen major[2].

The current system is to use psychological tests in schools at the secondary education level[3], with this psychological system it will be able to determine the results that can determine the direction of education a student can take, but the test system currently there are still manuals that do not use a sophisticated and computerized system, with a sophisticated system it will produce the right proposal to choose the major to be chosen in higher education[4].

The research problem raised is wanting to know an appropriate proposal in choosing a major in higher education[5], many students are still confused in choosing a major and in college, therefore this 
problem was raised in a study. which will produce a system proposal, and will maximize the AHP method in this research[6].

The method used in this research is to use quantitative methods, which use literature review as the basis for research, with a literature review, this research will refer to a previous journal, which has discussed a lot about the AHP method in taking decision, with the literature review method will be the basis for the renewal of the system that will be made in this research[7].

This research will produce how the AHP method helps in making decisions in choosing a major in a university, with the AHP method, it will be able to maximize the right decisions in choosing a major that is carried out by prospective students in a college[8].

\section{METHODS}

In this section we will discuss the research methods used[1], this section will also explain how the stages of research and images of the research method used, while the pictures and explanations can be seen below:

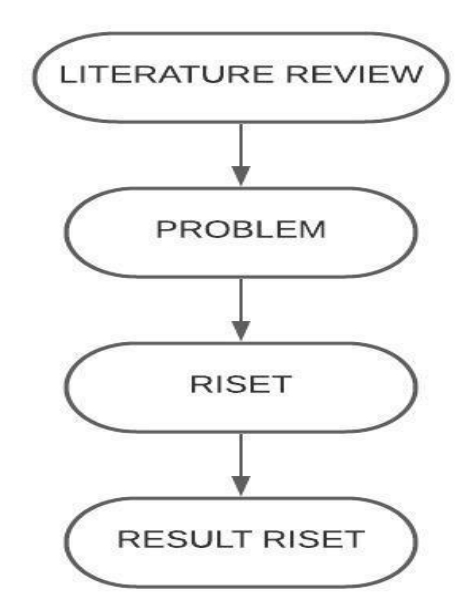

Figure 1. Research methods

Based on the image of the research method above, the explanation will be explained below:

\section{A. Literature Review}

The first stage in this research is to conduct a literature review based on previous research research[9], which refers to the same or similar research, by conducting a literature review, the author will add insight into science to increase the depth of ongoing research, by conducting literature reviews, then research. will be the basis for further research[10].

\section{B. Research Problems}

The second stage in this research is to find research problems based on journals that have been read and reviewed, it will determine the problems that can be raised in this research, based on previous research, the research problem this time can be a new problem, and has never been appointed in previous research studies[9].

C. Research 
The third stage in this research is to conduct the research, using existing data, the research can process the data that has been obtained, the purpose of this research is to find answers to the research problems raised, by conducting research, the research will be completed in accordance with flow of images from the research method adopted[11].

D. Research Results

The final stage in this research is getting the answers to the research problems raised, after finding the results of the research, these results can be implemented in existing systems, or can be developed for subsequent systems[12].

\section{RESULT AND DISCUSSION}

This section will discuss how the research process took place[13], and how the flow of a research was carried out, as for the explanations and pictures from the discussion of this research can be seen below:

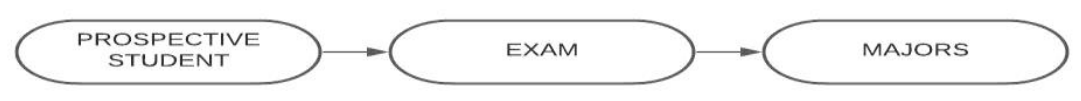

Figure 2. Research Directions

Based on the picture of the research direction above, it will be explained how the direction of the research took place, as for the explanation will be explained below:

- Prospective students

Prospective students are people who will take the test to determine what major to take in college, prospective students will also determine which major will be taken in the future[14].

- Exam

The test is the most important part of the research direction this time, with the test, students will produce information that can be used as a reference in processing data in a system, with the data, the AHP algorithm can process data so that it can produce a system proposal that can be used as a guide in majoring in college[15].

- Majors

The major is the result of processing data obtained through tests that have been carried out before, with a proposal for a department to be taken, students will not be confused in making decisions about what major to take in college[16].

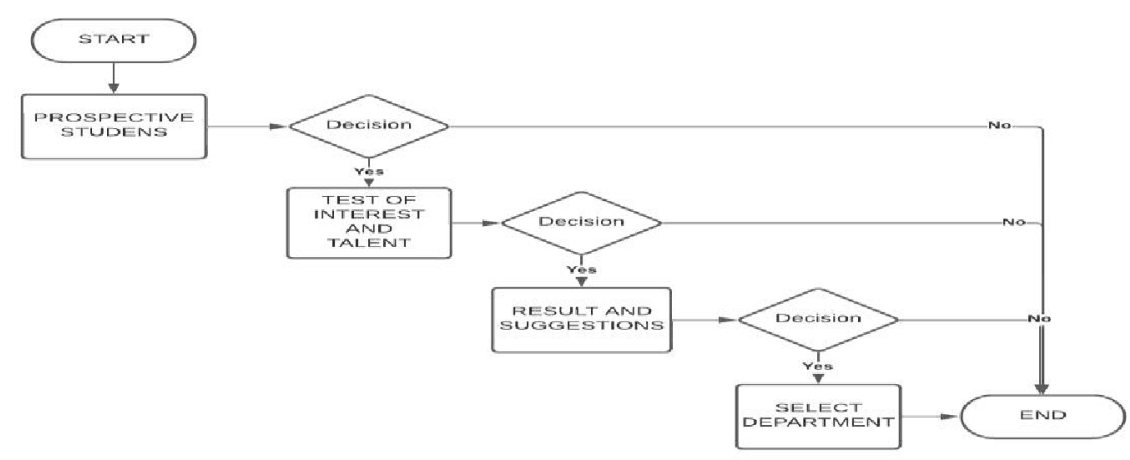

Figure 3. Department Selection Flowchart

Based on the flowchart image above, the explanation will be given below: 
Prospective students will undergo a test consisting of an interest test[17], a talent test and a psychological test, then when the test has been passed it will produce data that will be processed by the AHP algorithm[18], by processing the data it will be produce a decision that will be able to make a recommendation in decision making[19], to choose which department is the right one to choose for admission to higher education, with this proposal, prospective students will no longer be confused in choosing a major[19], because it is in accordance with the test results and data which has been processed by the AHP algorithm[20].

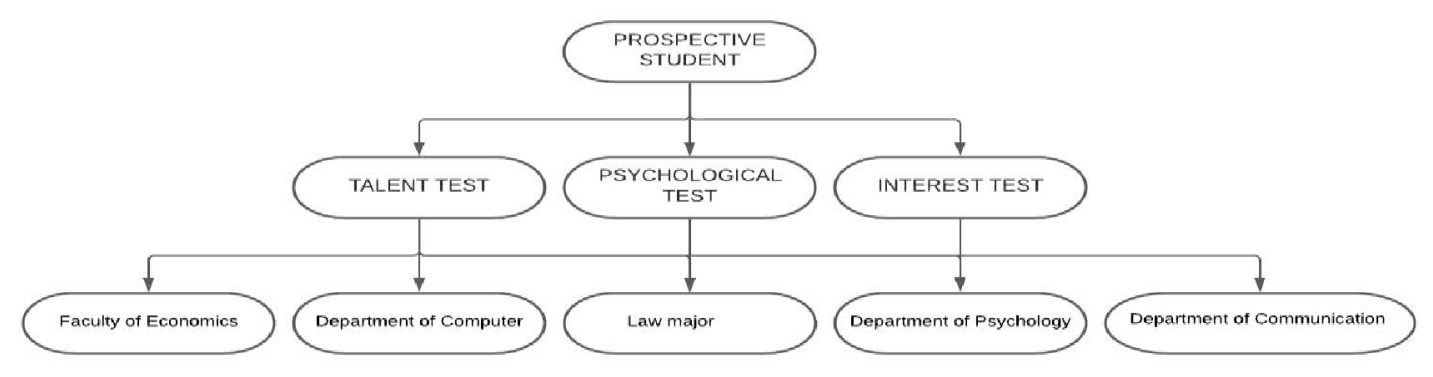

Figure 4. Application of the AHP Algorithm

- The first stage

The first stage of the AHP algorithm hierarchy is that prospective students as research objects, this research occurs when prospective students want to know which majors can be taken in college, based on the interests and talents of the prospective students[21].

- Second stage

The second stage of the ahp algorithm hierarchy in this research is the existence of interest tests, aptitude tests and psychological tests, with the 3 tests it will produce data that can be used by the AHP algorithm, with the data it will be able to produce what majors can be taken. by prospective students who match the student's interests and talents[22].

- Third phase

The third stage or the last stage in the AHP algorithm hierarchy is with a decision on what majors can be taken by prospective students[23], because the Department is the result of processing data according to the interests and talents of the prospective students[23].

\section{A. Data processing}

Table 1. Testing Table
\begin{tabular}{|c|c|c|c|}
\hline No & Tester & Parameter Tester & Code \\
\hline 1 & Testing 1 & Interest Test & C1 \\
\hline 2 & Testing 2 & Talent Test & C 2 \\
\hline 3 & Testing 3 & Psychology Tests & C \\
\hline
\end{tabular}

Table 2. Tabel Parameter

\begin{tabular}{|c|c|c|c|}
\hline No & Parameter Tester & Code & Scale \\
\hline 1 & Interest Test & C1 & $10-150$ \\
\hline 2 & Talent Test & C2 & $10-150$ \\
\hline 3 & Psychology Tests & C3 & $10-150$ \\
\hline
\end{tabular}

Table 3. Decision Table 


\begin{tabular}{|c|c|c|l|}
\hline No & Major Scale Value & Letter of Department Code & \multicolumn{1}{|c|}{ Decision } \\
\hline 1 & $10-100$ & E & Faculty of Economics \\
\hline 2 & $101-200$ & D & $\begin{array}{l}\text { Department of } \\
\text { Communication }\end{array}$ \\
\hline 3 & $201-300$ & C & $\begin{array}{l}\text { Department of } \\
\text { Psychology }\end{array}$ \\
\hline 4 & $301-400$ & B & Law major \\
\hline 5 & $401-450$ & A & Department of Computer \\
\hline
\end{tabular}

Table 4. Interests and Talent Test Participants Table

\begin{tabular}{|c|c|}
\hline No & Name of Participants at the Session \\
\hline 1 & FransSihombing \\
\hline 2 & Jims Sinaga \\
\hline 3 & Tomi Siahaan \\
\hline 4 & ArfianSyah \\
\hline 5 & Mega Lestari \\
\hline 6 & Diaz Sinaga \\
\hline 7 & ZeaNormansyah \\
\hline 8 & RamadhanaSaudin \\
\hline 9 & AndikaPratama \\
\hline 10 & Malik Akbar \\
\hline
\end{tabular}

Table 5. Interest and Talent Test Results Table

\begin{tabular}{|c|c|c|c|c|c|}
\hline No & Name of Participants at the Session & C1 & C2 & C3 & Total \\
\hline 1 & FransSihombing & 10 & 20 & 40 & 70 \\
\hline 2 & Jims Sinaga & 30 & 50 & 80 & 160 \\
\hline 3 & Tomi Siahaan & 20 & 20 & 50 & 90 \\
\hline 4 & ArfianSyah & 120 & 200 & 30 & 350 \\
\hline 5 & Mega Lestari & 50 & 90 & 40 & 180 \\
\hline 6 & Diaz Sinaga & 150 & 120 & 150 & 420 \\
\hline 7 & ZeaNormansyah & 30 & 40 & 60 & 230 \\
\hline 8 & RamadhanaSaudin & 120 & 85 & 89 & 294 \\
\hline 9 & AndikaPratama & 160 & 130 & 160 & 450 \\
\hline 10 & Malik Akbar & & & \\
\hline
\end{tabular}

Table 6. Interest and Talent Test Results Table

\begin{tabular}{|c|c|c|c|l|}
\hline No & Test Taker Name & Total value & Letter of Department Code & \multicolumn{1}{|c|}{ Majors } \\
\hline 1 & FransSihombing & 70 & E & Faculty of Economics \\
\hline 2 & Jims Sinaga & 160 & D & $\begin{array}{l}\text { Department of } \\
\text { Communication }\end{array}$ \\
\hline 3 & Tomi Siahaan & 90 & E & Faculty of Economics \\
\hline 4 & ArfianSyah & 350 & B & Law major \\
\hline 5 & Mega Lestari & 180 & D & $\begin{array}{l}\text { Department of } \\
\text { Communication }\end{array}$ \\
\hline 6 & Diaz Sinaga & 420 & A & $\begin{array}{l}\text { Department of } \\
\text { Computer }\end{array}$ \\
\hline 7 & ZeaNormansyah & 230 & C & $\begin{array}{l}\text { Department of } \\
\text { Psychology }\end{array}$ \\
\hline 8 & RamadhanaSaudin & 120 & D & $\begin{array}{l}\text { Department of } \\
\text { Communication }\end{array}$ \\
\hline 9 & AndikaPratama & 294 & C & $\begin{array}{l}\text { Department of } \\
\text { Psychology }\end{array}$ \\
\hline
\end{tabular}




\begin{tabular}{|c|c|c|c|l|}
\hline 10 & Malik Akbar & 450 & A & $\begin{array}{l}\text { Department of } \\
\text { Computer }\end{array}$ \\
\hline
\end{tabular}

Table 7. Interest and Talent Testing Table

\begin{tabular}{|c|l|c|}
\hline No & \multicolumn{1}{|c|}{ Parameters Tested } & Test result \\
\hline 1 & Input Value of Interests and Talent Test Examiners & OK \\
\hline 2 & Interests and Talent Test Data Verification & OK \\
\hline 3 & Interests and Talent Test Data Processing & OK \\
\hline 4 & Verification of Interest and Talent Test Values & OK \\
\hline 5 & Interests and Talent Test Decisions Output & OK \\
\hline
\end{tabular}

IV. CONCLUSION

The use of the AHP algorithm is appropriate if it is applied to data processing that can be a decisionmaking system, to decide what majors are right for prospective students based on interests and talents, with the cellphone algorithm it will provide the best advice based on the data obtained.

Future research can combine several algorithms into the AHP algorithm, to produce even more accurate decisions, because with several algorithms, decisions can be more in-depth, because they will be processed deeper based on existing data.

\section{REFERENCES}

[1] D. N. M. A. A. P. J. I. D. H. S. Y. C. Arman Syah Putra, "“Examine Relationship of Soft Skills, Hard Skills, Innovation and Performance: the Mediation Effect of Organizational Le," IJSMS, pp. 27-43, 2020.

[2] N. K. Dewi and A. S. Putra, "Perkembangan Gamification dan Dampak Game Online terhadap Jiwa Manusia di Kota Pintar DKI Jakarta," Jurnal Informatika Universitas Pamulang, vol. 5, no. 3, pp. 315-320, 2020.

[3] N. K. Dewi and A. S. Putra, "SISTEM PENUNJANG KEPUTUSAN PENERIMAAN KARYAWAN BARU DENGAN ALGORITMA GREEDY," Jurnal Visualika, vol. 6, no. 2, pp. 154-160, 2020.

[4] N. K. Dewi, I. Mulyana, A. S. Putra and F. R. Radita, "Konsep Robot Penjaga Toko Di Kombinasikan Dengan Pengendalian Virtual Reality (VR) Jarak Jauh," IKRA-ITH INFORMATIKA: Jurnal Komputer dan Informatika, vol. 5, no. 1, pp. 33-38, 2020.

[5] N. K. Dewi, . B. H. Irawan, E. Fitry and A. S. Putra, "Konsep Aplikasi E-Dakwah Untuk Generasi Milenial Jakarta," IKRA-ITH INFORMATIKA: Jurnal Komputer dan Informatika, vol. 5, no. 2, pp. 26-33, 2020.

[6] H. W. Fauzi, S. and S. Anwar, "ANALISIS PENGEMBANGAN JALAN TIDAK SEBIDANG (UNDERPASS) DI JALAN JENDERAL SUDIRMAN - JALAN SULTAN AGUNG KABUPATEN BREBES," Jurnal Konstruksi, Vol. VI, No. 3, Januari 2017, pp. 255-268, 2017.

[7] M. S. Hartawan, A. S. Putra and A. Muktiono, "Smart City Concept for Integrated Citizen Information Smart Card or ICISC in DKI Jakarta," International Journal of Science, Technology \& Management, pp. 364-370, 2020 .

[8] A. S. Putra, "Konsep Kota Pintar Dalam Penerapan Sistem Pembayaran Menggunakan Kode QR Pada Pemesanan Tiket Elektronik," TEKINFO Jurnal Ilmiah Teknik Informatika, vol. 21, pp. 1-15, 2020.

[9] A. S. Putra, "Analisa Dan Perancangan Sistem Pembelian Makanan Di Restoran Pada Masa Pandemic Coronavirus Disease 2019 (Covid-19)," Jurnal Esensi Komputasi ( Jurnal Esensi Sistem Komputer dan Informasi ), vol. 4, no. 2, pp. 10-15, 2020.

[10] A. S. Putra, "Efektifitas Sistem Jalan Underpass untuk Kota Pintar DKI Jakarta," Jurnal Informatika Universitas Pamulang, vol. 5, no. 3, pp. 220-227, 2020.

[11] M. Subani, I. Ramadhan, S. and A. S. Putra, "Perkembangan Internet of Think (IOT) dan Instalasi Komputer Terhadap Perkembangan Kota Pintar di Ibukota Dki Jakarta," IKRA-ITH INFORMATIKA: Jurnal Komputer dan Informatika, vol. 5, no. 1, pp. 88-93, 2020.

[12] I. M. Sari and E. D. Prajayanti, "PENINGKATAN PENGETAHUAN SISWA SMP TENTANG DAMPAK 
NEGATIF GAME ONLINE BAGI KESEHATAN," Program Studi Keperawatan, STIKES 'Aisyiyah Surakarta, pp. 1-9, 2017.

[13] I. Ramadhan, A. Kurniawan and A. S. Putra, "Penentuan Pola Penindakan Pelanggaran Lalu Lintas di DKI Jakarta Menggunakan Metode Analytic Network Process (ANP)," IKRA-ITH INFORMATIKA: Jurnal Komputer dan Informatika, vol. 5, no. 1, pp. 51-57, 2020.

[14] A. S. Putra, L. H. S. W. Harco, S. A. Bahtiar, T. Agung , . S. Wayan and H. K. Chu-, "Gamification in the eLearning Process for children with Attention Deficit Hyperactivity Disorder (ADHD)," Indonesian Association for Pattern Recognition International Conference (INAPR) IEEE, pp. 182-185, 2018.

[15] A. S. Putra, L. H. S. W. Harco , L. G. Ford , . S. Benfano and A. Edi , "A Proposed surveillance model in an Intelligent Transportation System (ITS)," Indonesian Association for Pattern Recognition International Conference (INAPR) IEEE, pp. 156-160, 2018.

[16] A. S. Putra and L. H. S. W. Harco, "Intelligent Traffic Monitoring System (ITMS) for Smart City Based on IoT Monitoring," Indonesian Association for Pattern Recognition International Conference (INAPR) IEEE, pp. 161-165, 2018.

[17] A. S. Putra and . R. R. Fatrilia, "Paradigma Belajar Mengaji Secara Online Pada Masa Pandemic Coronavirus Disease 2019 (Covid-19)," MATAAZIR: Jurnal Administrasi dan Manajemen Pendidikan, pp. 49-61, 2020.

[18] A. S. Putra and . H. Kusuma, "Pengembangan Sistem Career Center untuk Departemen Konseling dan Pengembangan Karir di Institut Teknologi Budi Utomo," Jurnal Khatulistiwa Informatika, pp. 133-143, 2015.

[19] A. S. Putra, " "Smart City : Ganjil Genap Solusi Atau Masalah Di DKI Jakarta"," Jurnal IKRA-ITH Informatika Vol 3 No 3, ISSN 25804316, , 2019.

[20] A. S. Putra, " "Smart City : konsep Kota pintar di DKI Jakarta"," Jurnal TEKINFO, Vol 20, No 2, Hal 1-111, ISSN 1411-3635, 2019.

[21] A. S. Putra, "Teknologi Informasi (IT) Sebagai Alat Syiar Budaya Islam Di Bumi Nusantara Indonesia," Seminar Nasional Universitas Indraprasta ( SINASIS ), pp. 200-215, 2020.

[22] A. S. Putra, "Penerapan Konsep Kota Pintar dengan Cara Penerapan ERP (Electronic Road Price) di Jalan Ibu Kota DKI Jakarta. Jurnal Informatika Universitas Pamulang, 5(1), 13-18.," Jurnal Informatika Universitas Pamulang, 5(1), 13-18., pp. 13-18, 2020.

[23] A. S. Putra, H. L. H. S. Warnars, B. S. Abbas, A. Trisetyarso, W. Suparta and C.-. Ho Kang, "“Gamification in the e-Learning Process for children with Attention Deficit Hyperactivity Disorder (ADHD)"," 1 st 2018 Indonesian Association for Pattern Recognit INAPR, pp. 182-185, 2019.

[24] A. S. Putra, "“Penggabungan Wilayah Kota Bekasi Dan Kota Tangerang Ke Wilayang Ibu Kota DKI Jakarta Berdasarkan Undang-Undang Nomor 23 Pasal 32 Tahun 2019 Dapat Membantu Mengwujudkan DKI Jakarta Menjadi Kota Pintar"," Jurnal IPSIKOM VOL 7 No. 2, 2019. 